\title{
西洋技術導入期における木造学校建築の架構形式の変遷過程 \\ THE EVOLUTION OF FRAMING SYSTEMS IN WOODEN SCHOOLS BUILT DURING EARLY WESTERNIZATION
}

\author{
八木幸二*, 藤 嶋 忠**, 堀 江 亨***, 八代克彦**** \\ Koji YAGI, Tadashi FUJISHIMA, Tooru HORIE \\ and Katsuhiko YASHIRO
}

\begin{abstract}
This paper intends to clarify the evolution of wooden framing systems in Westernstyle schools during the Meiji and Taisho periods. At the beginning of Meiji,framing was irregular as some columns were placed based on window position as well as the traditional module. In the middle of Meiji,two framing systems co-existed:one based on window arrangement and the other based on the traditional module. From late Meiji,the width of windows was neither determined by the frame arrangement nor the traditional module. This transformation reveals the process of standardization within wooden-frame schools in terms of columns and windows arrangement.
\end{abstract}

\section{Keywords: mooden schools, framing systems, traditional module, column spacing, width of windoms 木造学校建築、架構形式、従来モデュール、柱間、空幅}

1. 序

明治期から大正期までは、軸組構法による木造建築が 西洋建築技術を導入し摄取する過程において、それまで の伝統的な構法から変化していく時期であるといえる。 とりわけ学校建築をはじめとする公共建築物には、外観 表現に文明開化としての象徵性を賦与するために、西洋 の様式をまとったものが求められていた。

明治期の学校建築に関する研究には、個別の学校を扱 ったもの、復元的考察を行おうとしたもの、文部省の規 定に着目したもの”などがあり、架構形式に関しては、 主として小屋組の変遷が注目されてきた ${ }^{2)}$ 。こうした既 往の研究においては、外観意匠、平面形式、構造が個々 に取り上げられているが、外観構成を成立させるための 架構の要素としての柱、梁、小屋組相互の関連がどのよ うに変遷してきたかという点が明確になっていない。

本研究は、木造学校建築の外観の要素である空の配置 と、その周囲に架構される柱、梁、小屋組の各要素の位
置関係を分析することにより、西洋建築技術の影響を受 けた架構形式の变遷過程の一端を明らかにすることを目 的としている。研究対象は、表-1、写真一 1 に示した 明治初期から大正期における、西洋建築の外観を呈する 学校建築22例 ${ }^{3}$ （大工棟梁の設計による9 例、文部省設 計による5 例、設計者不明 8 例）とする。分析資料は、 設計図書、修理工事報告書等 ${ }^{4)}$ の図面、写真に加え、筆 者による実測調查から得た。分析対象は、図一 1 に示す ように正面外観を構成している空、悹に取り合う軸組お よび小屋組とする。

分析の手順は、まず軸組に関して、空幅と柱間隔の一 対の関係を示したのち、部屋単位で見た柱配列の類型を 抽出することにより柱と空の配置の整合性を分析する。 つぎに、軸組と小屋組の関係を取り上げ、小屋組構法の 変化を個々の事例から言及したのち、柱之梁の配置の整 合性を分析する。最後に、柱、梁、空の相互関係からみ た全体架構の変遷過程を考察する。
* 東京工業大学工学部建築学科 教授 $\cdot$ 工博

** 大林組 修士(工学)

***, 日本大学生物資源科学部森林資源科学科 助手・博士 (工学)

**** 札幌市立高等専門学校 専任講師・博士 (工学)
Prof., Dept. of Architecture, Faculty of Engineering, Tokyo Institute of Technology, Dr. Eng.

Obayashi Corporation, M. Eng.

Research Assoc., Dept. of Forest Science and Resources, College of Bioresource Sciences, Nihon Univ., Dr. Eng.

Lecturer, Sapporo School of the Arts, Dr. Eng. 


\section{2. 軸組における㥶と柱の配置}

（1）空幅と柱間隔

研究対象に見られた垧回りの軸組構成を図一 2 に示し た。窓の両側が柱と離れており両側とも壁になっている もの、空の片側が柱に接しもう一方が壁になっているも

表一 1 研究対象一覧

\begin{tabular}{|c|c|c|c|c|}
\hline 号 & 建築年 & 名称 & 設計者 & 文部省規定 \\
\hline 1 & 明 8 & 中込学校 & 大工棟梁 & \multirow{7}{*}{$\begin{array}{l}\text { 「学制」発布 (明5) } \\
\text { 「小学校建設図」(明6) }\end{array}$} \\
\hline 2 & 明 9 & 楖原学校 & 大工棟梁 & \\
\hline 3 & 明 9 & 開智学校 & 大工棟梁 & \\
\hline 4 & 明11 & 尾県学榕 & 不明 & \\
\hline 5 & 明11 & 群馬県衡生所英医学校 & 大工楝梁 & \\
\hline 6 & 阴 11 & 格致学校 & 不明 & \\
\hline$\frac{8}{7}$ & 明13 & 岩科学校 & 大工楝梁 & \\
\hline 8 & 明15 & 三福学校 & 不明 & \multirow[t]{4}{*}{ 「文部省示論」(明15) } \\
\hline 9 & 明 18 & 吾婁第三小学校 & 不明 & \\
\hline 10 & 明 20 & 泊育英小学校 & 大工棟梁 & \\
\hline 11 & 明 21 & 登米小学校 & 大工棟梁 & \\
\hline 12 & 奛 21 & 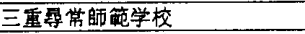 & 大工熼梁 & \multirow{11}{*}{ 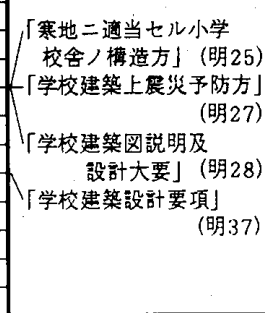 } \\
\hline 13 & 明 22 & 福島県專常中学校 & 不明 & \\
\hline 14 & 明 23 & 東京音楽学校奏楽室 & 文部省 & \\
\hline 15 & 盟 32 & 大阪府第四中学校 & 不明 & \\
\hline 16 & 明 34 & 山形師篹学校 & 不明 & \\
\hline 17 & 明 34 & 札幌票学校昆虫学及隼虫学教室 & 文部省 & \\
\hline 18 & 明 42 & 東北帝国大学晨科大学林学教室 & 文部省 & \\
\hline 19 & 明 43 & 米沢高等工業学校 & 文部省 & \\
\hline 20 & 明 45 & 盛岡高等畺林学校 & 文部省 & \\
\hline 21 & 大11 & 城南星掌高等小学校 & 不明 & \\
\hline 22 & 大14 & 水元小学校 & 天工棟梁 & \\
\hline
\end{tabular}

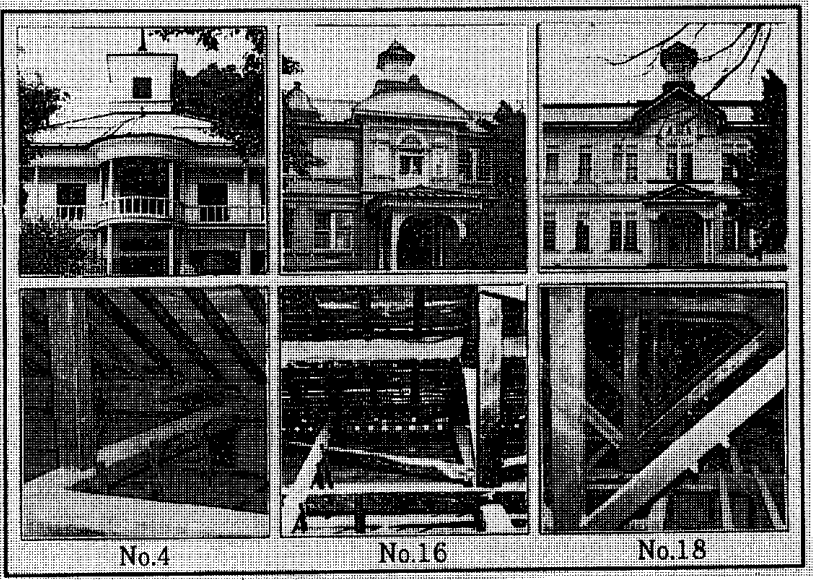

学真-1 対象例の外観および小屋組

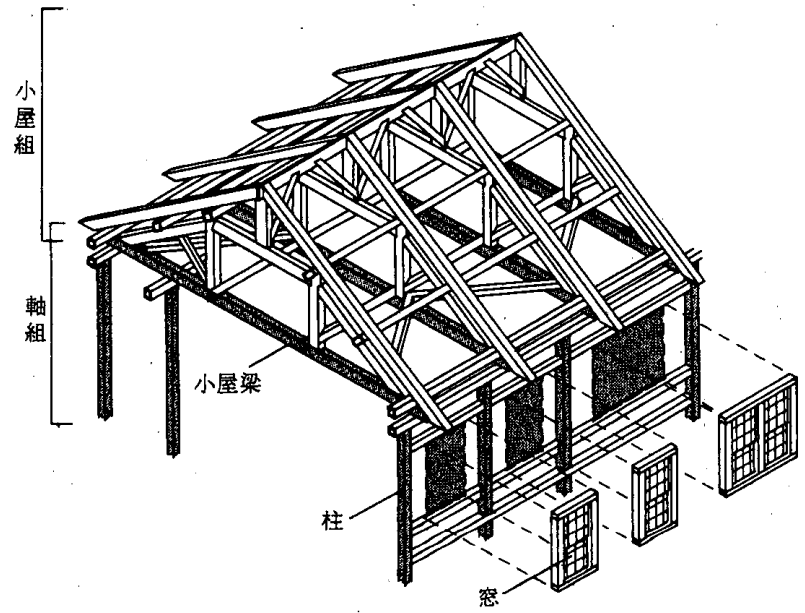

図-1 分析対象架構
の、公の両側が柱に接しているものがあり、各々の配置 に対応して窓回りの軸組は柱・貫による構成と、柱・間 柱による構成が見られた。図ー3はこの分類に従い、各 事例の柱間の軸組構成と空の配置を設計者の属性がわか るように示したものである。図ー3から、大工棟梁によ る設計では、柱間と空の位置関係は様々であり、また柱 間には貫を入れているものがほとんどである。一方、明 治中期以降の文部省による設計のものはすべて、空の両 脇に柱を配し、軸組には間柱を入れている。

図ー 4 は空幅と柱間隔の対応を示したものである。柱 間隔は部材の心心とし、空幅は正面からの見付け幅とし た。なお、各事例において、穴幅と柱間隔の関係が一種 類でない場合には、柱間隔が最小のものの対応を記して いる。図中の一点鎖線は柱間隔いっぱいに空を納めた場 合に相当し、この線に近いほど柱と㝐が近接して配置さ れることになる。この図から、大工棟梁の設計の多くは、 6尺もしくは3尺という従来のモデュールにしたがって 柱を配置し、その間で 2 尺から 4 尺までを中心とした様 々な寸法の空幅を採用している。これに対し、文部省に よる設計では、柱間隔が従来のモデュールに従っておら ず、しかも柱間隔 4 尺程度、空幅 3 尺程度の一定值に近 い寸法となっている。

これらから、大工棟梁は 6 尺を基本単位とする従来の 柱間のなかで空を割り付けようとしていたことがわかる。 一方、明治中期以降の文部省の設計では、従来のモデュ ールにとらわれずに空の配置を計画しょうとしていたこ とがうかがわれる5゙。

（2）部屋単位でみた柱と空の配置の整合性

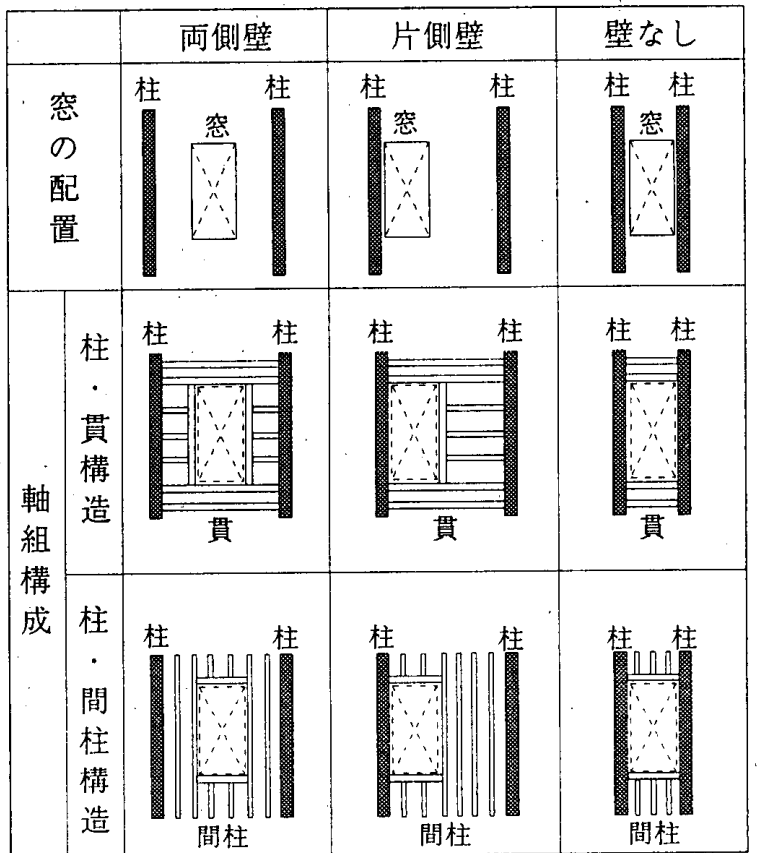

図一２葖回りの軸組構成 
図一 5 は、部屋単位でみた柱の配列を、従来のモデュ 一ルおよび空配置との関係から分類して示したものであ る。従来からの 6 尺を原則としたモデュールに従うもの を従来型、従来モテュールから逸脱し規則的な空の割り 付けに対応したものを空対応型とする。なお、空の割り 付けに影響されていても柱が従来のモテュールないしは これを調整した配列を成している場合は従来型と見なす ものとする。さらに、空回りの軸組および柱と間仕切り の位置関係から、従来型を $\mathrm{I} \sim \mathrm{IV}$ に、悹対応型を $\mathrm{i} \sim$ i i iに細分類した。また、各類型の柱、窓、間仕切りの 位置関係を例示した。

従来型の I は、6 尺の等間隔で柱を割り付けているも ので、柱間における空の配置はまちまちである。すなわ ちこの型は、従来モデュールに従って配された架構が先 行し、その柱間のなかで所要寸法の開口部を設けたもの と見なすことができ、従来型のなかでも最も従来モデュ 一ルの制約が強い型であるといえる。II，IIIは、各々 3 尺もしくは 4 尺の等間隔で柱を配したものである。これ らはいずれも柱と穴の配置が対応していることから、6 尺を基準とするモデュールに追従しながら、柱の割り付 けを㥶幅に合わせようとする意図がみられる。IVは、6 尺モデュールを基調としながらも、図示例のように部分 的に 6 尺 3 スパンを 4 つ割りとして柱間を䆔幅に合わせ ようとしたものなど、6尺モデュールを部分的に調整し

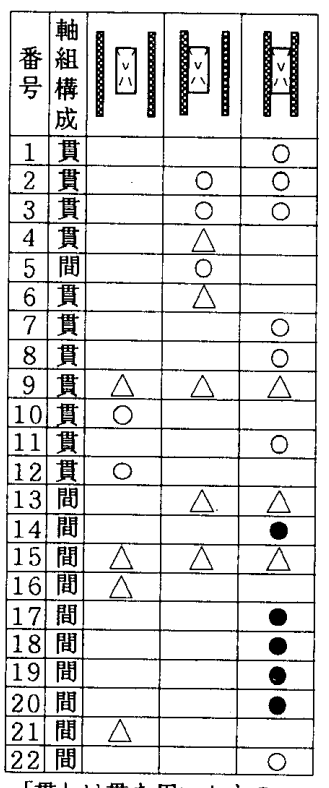

「貫」は貫を用いたもの

「間」は間柱を用いたもの。

\section{○工棟梁の設部 \\ 文部省の設計 \\ $\triangle$ 不明}

図 -3 柱間の軸組構成 と空の配置

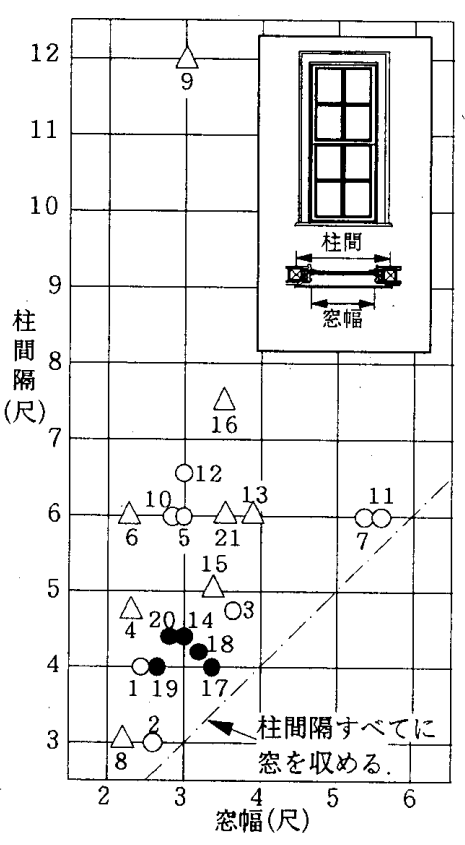

大工棟梁の設計 文部省の設計 $\triangle$ 不明 図 - 4 空幅と柱間隔の関係
た不規則な型である。

一方、空対応型の $\mathrm{i}$ は、6尺を基準としたモデュール に従わず、かつ空の両端に配された柱配列とそうでない 柱配列を含んでおり、空対応型のなかで最も柱と窓の整 合性の低い型である。これに対してiiは、空幅によるモ デュールと壁によるモデュールを交互に並べた型であり、 i i i は連空に対応してさらにモデュールが複雑化した型 である。これらはいずれも外観の規則性、対称性を意図 した空の割り付けに柱列が整合した型である。

従来型と䆔対応型を設計者別に見ると、従来型は大工 棟梁に、䆔対応型は文部省におおむね対応している。図 一 5 において従来型を通覧すれば、大工棟梁が西洋建築 の外観を表現しようとした際に、柱間の空配置をまちま ちにした場合も、従来モデュールを調整することで部分 的に空幅に合わせようとした場合も、いずれも従来の日 本の寸法体系を基点として軸組設計をしようとしていた といえる。他方、空対応型に見られる文部省の設計は、 従来モデュールから解放され、空配置の規則的な繰り返 しによって西洋建築の外観を表すための計画性を有して いたと見ることができる。

\section{3. 軸組之小屋組の関係}

(1) 小屋組形式の変化

図一 6 は分析対象において見られた小屋組を、叉首組

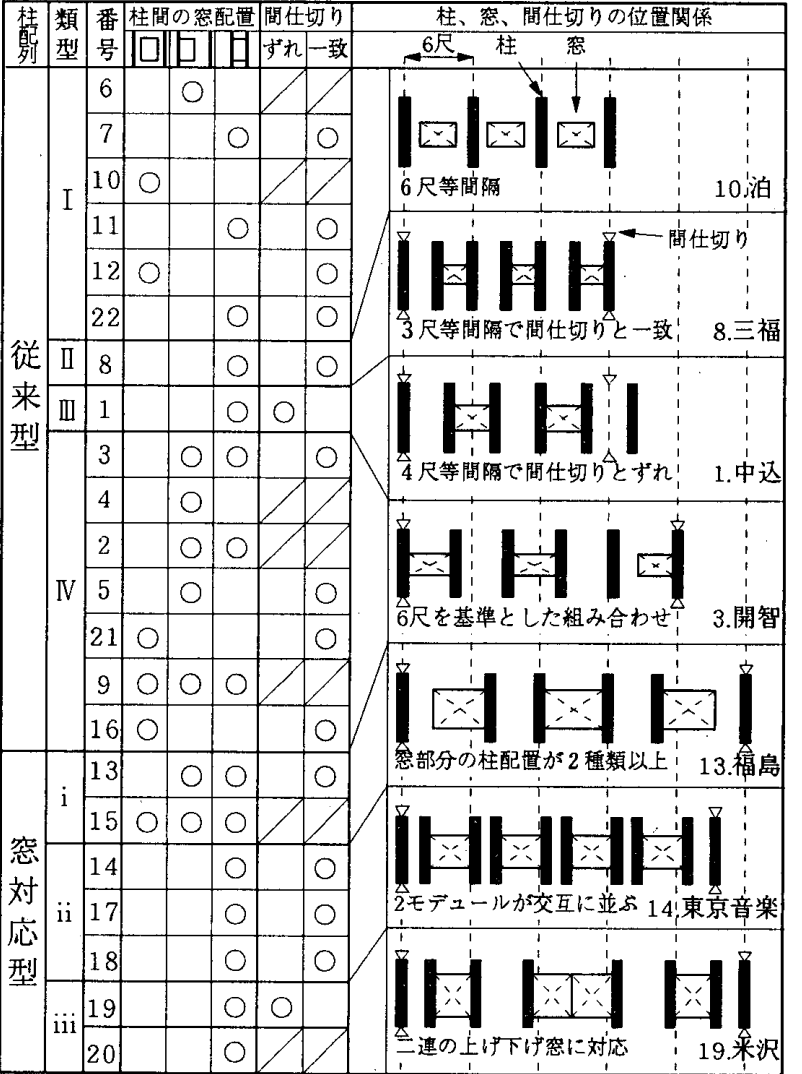

図一 5 柱配列の類型 


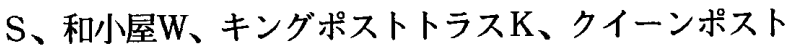
トラスQに分類し、梁間との関係を設計者ごとに年代に より示したものである。図中、明治初期に見られる事例 3 は洋小屋であるが、同時期の和小屋に比べて大梁間に 対応できる洋小屋の利点をいち早く取り入れたものと推 察される。そしてこの一例を除けば、大工棟梁の設計に よるものは、事例10，11に見られるように、明治20年代 初頭より和小屋から洋小屋へ小屋組形式が移行する傾向 が見られる。この移行の時期は、文部省が洋小屋の使用 を規定した「学校建築図説明及び設計大要」の明治28年 よりもさらに早い6)。ここから、大工が西洋建築技術を 積極的に先取りしようとした意眓を液み取ることができ $る^{7}$ 。

また、文部省の設計による小屋組では、当初から純粋 な洋小屋となっているが、大工棟梁によるものでは、図 - 7に示すように、初期の洋小屋の部材の取り合いに和 小屋との類似性が認められる K'， Q' が現れている。 たとえば、aでは小屋梁が柱の上に折置に架かっている。 $\mathrm{b}$ は、斜材を小屋梁の下部の敷桁との関連で付加したも のであり、小屋の荷重を敷桁に伝える取り合いになって いる。cは、3部材が一点に集まらず純粋なトラスを形 成しないもので、ピン接合の原則を無視し、斜材を和小 屋の貫と同じ取り合いにしている。 $\mathrm{d}$ は、二重梁部分の 斜材が通常のクイーンポストトラスと異なって構成され るもので、事例20の文部省設計を除いた残り 3 例のすべ てのクイーンポストトラスで見られた。

このように、和小屋から洋小屋への移行期には、大工 は斜材を含めた部材の取り合いが一点で集まるようなピ ン接合を意識せず、和小屋の水平・垂直材と同様に部材 を構成していたと考えられる。すなわち大工棟梁は新し

\begin{tabular}{|c|c|c|c|c|c|}
\hline \multirow[b]{2}{*}{$\begin{array}{l}\text { 類型 } \\
\text { 年代 }\end{array}$} & \multirow[b]{2}{*}{ 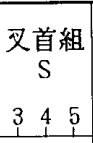 } & \multirow[b]{2}{*}{ 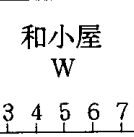 } & \multicolumn{3}{|c|}{ 洋小屋 } \\
\hline & & & 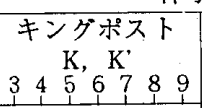 & 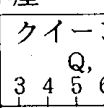 & 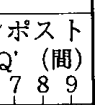 \\
\hline 明治元年 & & & & & \\
\hline $\begin{array}{r}(1868) \\
\text { 明治 } 10 \text { 年 }\end{array}$ & & $\begin{array}{lll}5 & 1 \\
5 & 0\end{array}$ & & & $\begin{array}{c}3\left(Q^{\prime}\right) \\
\vdots \\
0\end{array}$ \\
\hline 明治 20 年 & 8 & $\begin{array}{l}\triangle \delta_{4} 4 \\
\triangle 89 \\
\end{array}$ & $10\left(\mathrm{~K}^{\prime}\right)$ & & \\
\hline $\begin{array}{r}(1887) \\
\text { 明㕸 } 30 \text { 年 }\end{array}$ & & 12 & $141\left(\mathrm{~K}^{\prime}\right) 13(\mathrm{~K})$ & & \\
\hline $\begin{array}{r}\text { (1897) } \\
\text { 明治40年 }\end{array}$ & & & 17 & $\begin{array}{c}\triangle \\
16\left(Q^{\prime}\right)\end{array}$ & $\triangle \triangle_{15}$ \\
\hline $\begin{array}{l}(1907) \\
\text { 大正6年 }\end{array}$ & & & $18 \stackrel{0}{\circ}$ & & 20 \\
\hline (1917) & & & $\begin{array}{rl}22 & \triangle \\
0 & 21 \\
\end{array}$ & & \\
\hline $\begin{array}{r}(1927) \\
07\end{array}$ & E工梗 & $\begin{array}{c}\vdots \\
\text { D設計 }\end{array}$ & 文部省の設計 & $\triangle$ 不明 & \\
\hline
\end{tabular}

図一 6 小屋組と梁間の関係
い架構の要素である斜材を採用するのに、日本従来の架 構法で対応しようとしていたといえる。

\section{（2）柱と梁の配置の整合性}

日本従来の柱・梁構造により西洋建築の外観を表わそ うとしたときの軸組と小屋組における部材の割り付け上 の整合性を示すための指標として、図ー8のように梁が 柱に載る度合から柱と梁の整合度を定めた。整合度は、 梁と柱の一対の関係において、梁が柱に載る度合いを示 している。梁と柱の位置が一致する場合を 1 、両者が位 置の一致する部分がない場合を 0 とし、梁幅の一部が柱 に載る場合を 0.5 とする。そして部屋上部にかかる複数 の梁について各々求めた整合度の平均値を当該事例の整 合度とする。図一 8 には、各事例の柱と梁の整合度を求 め、年代により示した。最も整合度の高い値 1 を中心軸 とし、左方に寄ると和小屋で柱と梁が不整合、右方に寄 ると洋小屋で柱と梁が不整合となるように配している。

図一 8 から、柱と梁の整合性は、和小屋で不整合の時 期から、洋小屋への移行期における整合の時期を経て、 洋小屋で不整合となる時期に至っている。明治初期に現 れている和小屋による架構では、柱と梁の整合性が低い。 これは、桁回りを京呂とし、䡛桁を介して荷重を伝える 形式としているためであり、梁と柱の間に生じた不整合 を納めるために従来の架構法で対応したものといえる。 明治中期には小屋組は和小屋から洋小屋へ移行しつつあ り、柱と梁の配列を合わせ、軸組と小屋組の整合性が高 まっている。ゆえにこの時期には、架構全体として合理 的に荷重を伝達しようとする意図がうかがわれる。明治 後期以降になると、小屋組はすべて洋小屋となり、柱と 梁の配置が再び不整合となる傾向が見られる。このこと

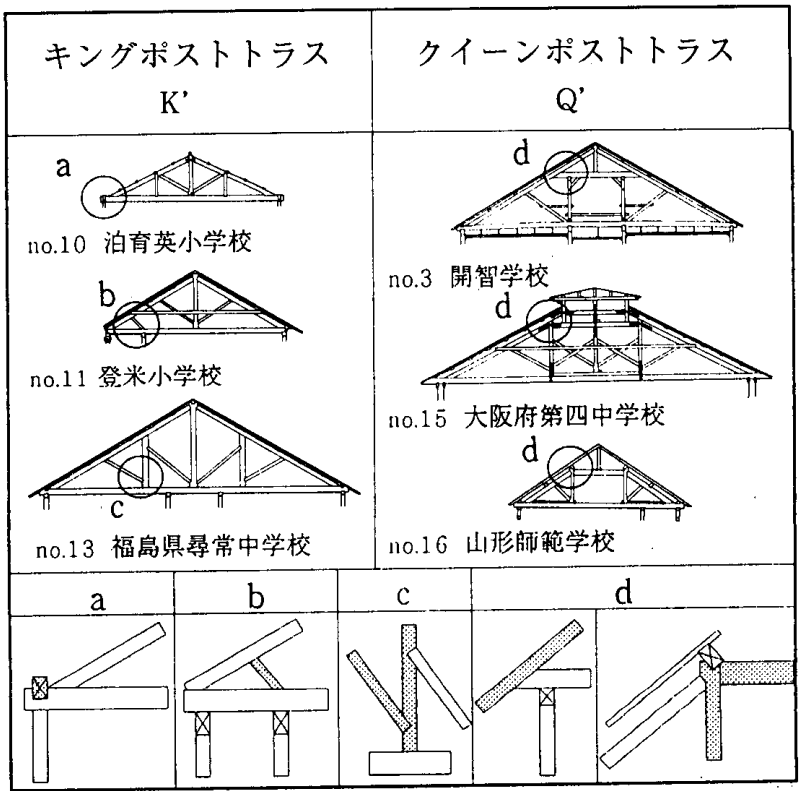

図-7 洋小屋のなかにみられる和風要素 
から、この時期には、和小屋ほど小屋梁の断面積を必要 としない軽量な洋小屋の利点を活かした架構となってい ると考えられる。

\section{4. 柱、梁、害の相互関係からみた全体架構の変遷}

軸組の分析における柱配列の類型 I IV、 $\mathrm{i} \sim \mathrm{i}$ i i と、 小屋組形式の和洋により、柱、梁、空の配置の相互関係 を年代順に図式化したものが図－9である。以下、各年 代における部材配置を、外観構成および従来モデュール との関連において考察する。

明治初期の大工棟梁による事例1, 2,3,5は、そのほと んどが和小屋であり、柱配列の類型而またはIVに属して いる。すなわち軸組において柱の配置は従来の 6 尺モデ ユールを踏襲しようとしながらも、空の割り付けに影響 され、柱の配置が不規則になったものである。ところが 小屋梁はほとんどが 6 尺モデュールで配されたために、 柱と梁の配置には不整合を生じている筒所がある。ゆえ に、この時期には空の割り付けに軸組の柱配列を追従さ せようとしたものの、架構全体の部材配置までは外観構 成に対応していなかったことがわかる。

明治中期には、大工棟梁による和小屋から洋小屋への 移行期の架構亡、文部省による洋小屋の架構が現れてい る。大工棟梁による事例7,10,11,12では、和小屋、洋小 屋にかかわらず柱配列の類型 I に属しており、柱と梁の 一致している。これらは 6 尺モデュールに従って柱と梁 を割り付け、穴については柱間に所要の窓幅とその余剰 部分としての壁を配したものと見ることができる。すな

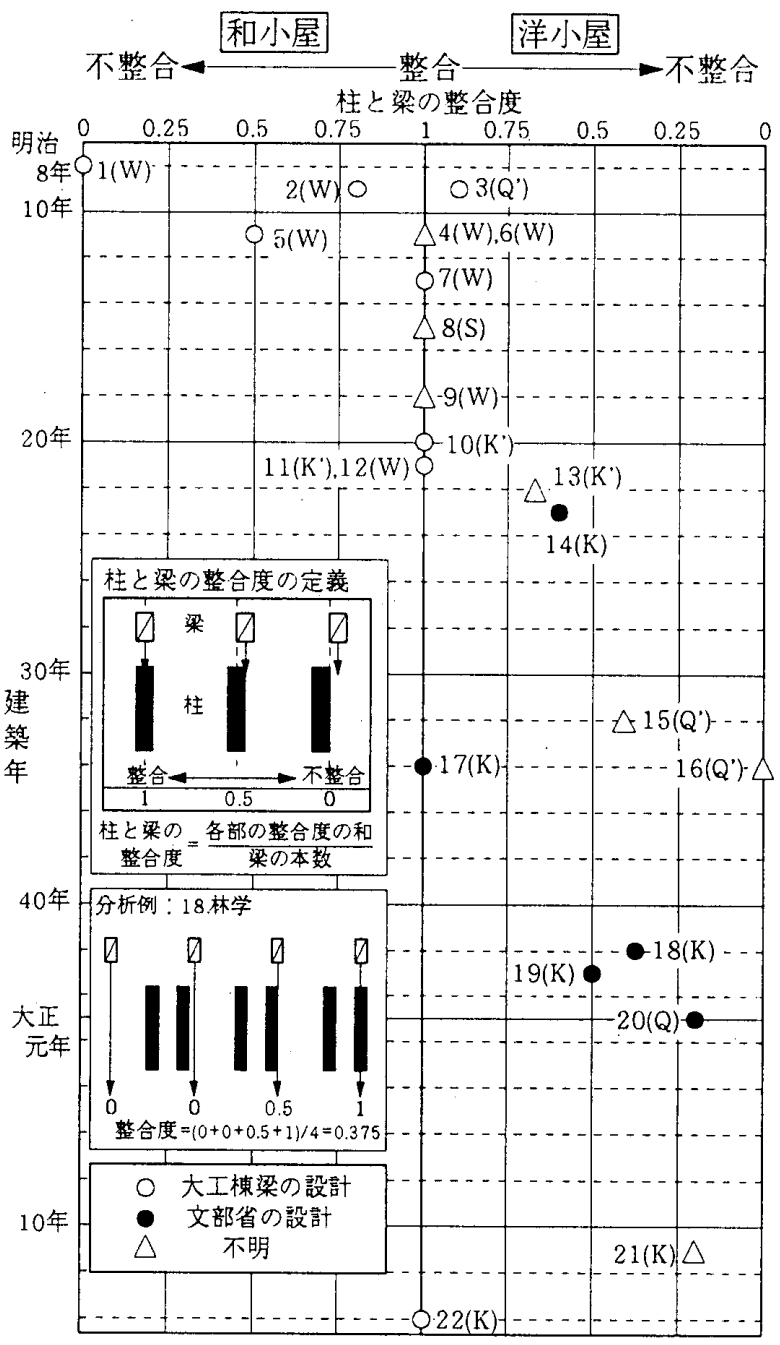

図 -8 柱と梁の整合度の変遷

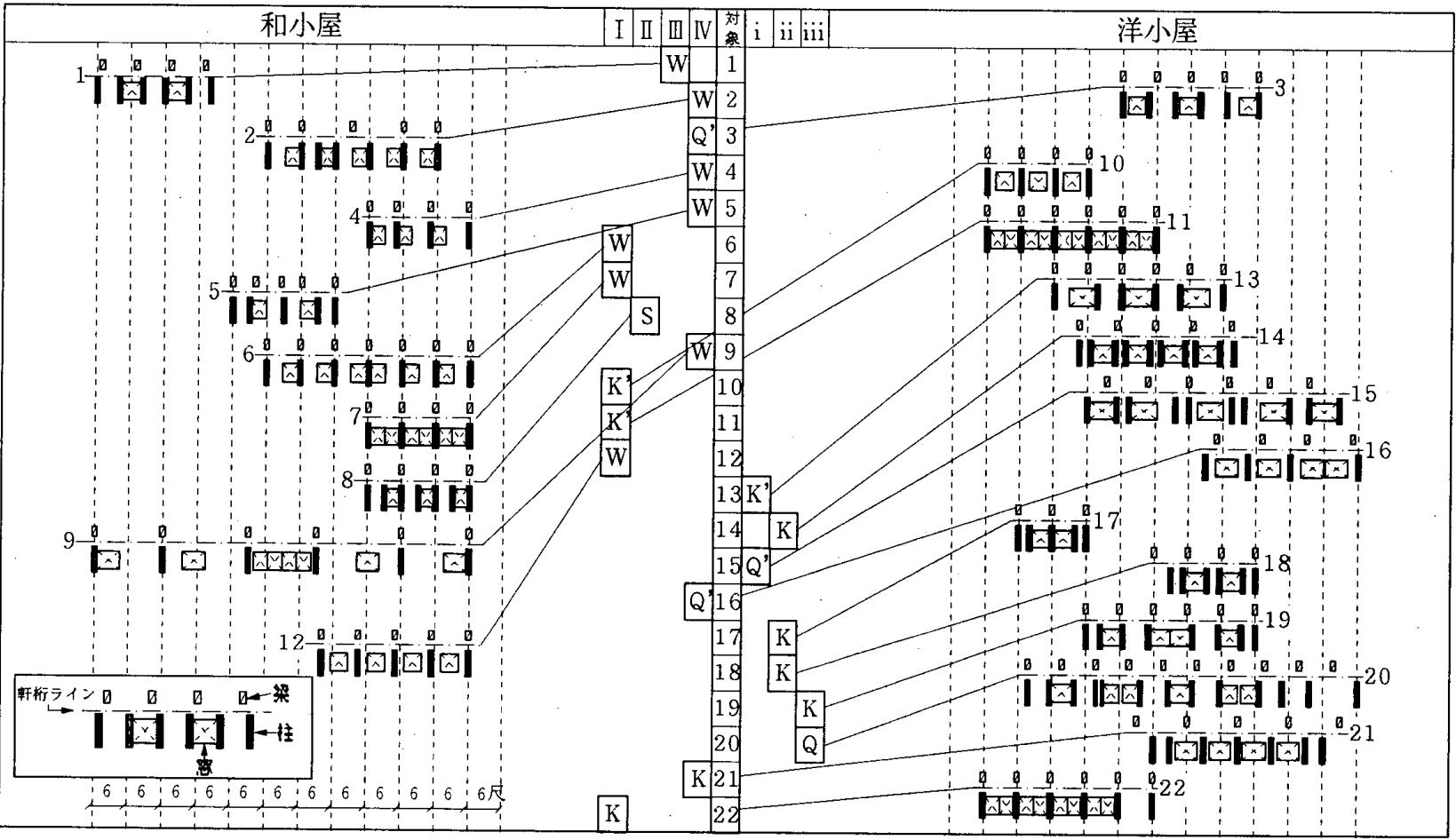

図-9 柱、梁、空の相互関係 
わち架構の整合性を従来モデュールに従って優先し、外 観構成を架構とは独立して計画しているといえる。一方、 文部省による初期の事例14，17は、柱配列の類型が空幅 に対応したiiとなっている。これらは左右対称の空割に 柱割を合わせており、とくに事例14では、梁を空の取り 付かない柱間に配すればよいという割り切りがうかがわ れる。すなわち外観構成が要求する割り付けを優先し、 架構をこれに従属させようという意図をみることができ る。

このように明治中期には、大工棟梁と文部省とで全く 異なった設計思考があったといえるが、前者による事例 12 と後者による事例14に共通して、6 尺以外のモデュー ルを設定して柱、悹、壁、梁を規則的に配したものが現 れており、両者ともに従来モデュールから逸脱しようと する積極的な気運が生じているとみることができる。

明治後期以降には、大工棟梁によるものも文部省によ るものも含め、総じて洋小屋となっている。これらの事 例18，19，20においては、柱配列の類型は空幅に対応した ii, iiiとなっている。ここでは従来モデュールとは独立 した複雑な窓配置に柱割が追従しており、その一方で、 梁が柱とは無関係に空の直上にも配されている。すなわ ち、柱と空の対応がより緊密化し、梁と柱の配置の不一 致にはこだわらない構成である。したがって、これらの 形式では、洋小屋という架構形式への理解とともに、そ れまで軸組との関連の強かった梁が、小屋組部材として 独立して扱われるようになったといえる。

\section{5. 結}

本研究は、明治・大正期における西洋建築の外観をも つ木造学校建築を取り上げ、外観構成に対応する架構の 変遷過程を、部材配置の整合性と従来モデュールへの適 合性の観点から考察した。その結果を、西洋建築を志向 しようとした従来の軸組構法の変容という観点から整理 しなおせば、以下のように要約される。

明治初期においては、軸組材である柱は、空の配置に も、従来のモデュールにも従属しえない中途半端な配置 となり、他方、梁は従来の 6 尺間隔で配されたために柱 の配置と整合しなかった。これは、西洋建築の外観を導 入しようとするにあたり、空という建築要素を架構のな かでどのように位置づけるのかという考え方か整理しき れていなかったために、悹周辺の軸組部分に寸法決定上 の戸惑いが表れたものと解することができる。これに対 して明治中期以降における和小屋から洋小屋への転換期 は、従来のモデュールを優先して柱、梁を配し、愙を架 構とは独立して配するという考え方と、外観構成を優先 して柱と悹を配し、梁と軸組との関係を割り切った考え 方とが並存する過渡的な時期であるといえる。同時に、 そのいずれの考え方においても、従来とは異なる新たな
モデュールを創出しようとする積極性が表れている、と 評価できる。一方、明治後期以降においては、洋小屋に 対する理解が高まった結果、小屋組が軸組とは独立して 配され、また軸組においては柱と空の対応がより緊密化 し外観構成の秩序に寄与しているといえる。これは、開 口部の寸法決定の判断を、小屋架構の配置にも従来のモ テュールにも依存しなくなった形式としてとらえること ができる。

Фえに、このような変遷は、西洋建築の外観の構成要 素としての空を設計しようとした際に、日本の伝統的建 築の軸組において不可分であった柱間と開口部がそれぞ れ独立して、異なる寸法上の概念を生んでゆく過程であ るとみなすことができる。

注

1) 学校建築史を体系的に报った研究として、菅野誠、佐藤㖣： 「日本の学校建筑」、文教ニュース社、1983.があるが、こ こでは明治中期以降の学校建策の標準化の一因として文部省 の規定を取り上げている。その特徽としてたとえば、外観を 筫朴堅军にする、といったことや、明治初期の中廊下式に代 わっての片廊下の操用、といったことが挙げられている。

2 ) 村松貞次郎 : 幕末 ·明治初期洋風建筑の小屋祖とその発達、 日本建学会論文報告集第63号、1959.10は、小屋組がいか にして合理的な洋風トラスに変容していったかということに ついて考察している。また、長尾充: 太政官公文録中の建縩 仕梯書加らた明治初期の建築技術, 北海道大学学位論文、 1992では、建筑任椂書における小屋組の変塄過程が示されて いる。

3 ) 設計者は、保存修理工事報告書およひ既往研究を参照し確認 した。なお、建物名称は原則として創建時のものを用いた。

4 ）目面の出典については、本文・表一1に揭げる事例10，15は 調查報告書を、17, 181 北海道大学所蔵龱面を、20,21,22は 改修、堷箖または移築工事四面を、他は保存または復元修理 工事報告書を参照した。

5 ) 宮本雅明 : 明治期における文部省営結組織の構成と改革 高 等教育施設の史的研究 $(1) 、$ 日本建築学会諭文報告集第 292 号、1980.6によれば、建箖設計組瀻としての文部省営結組瀻 は、明治16年の山口半六への設計委託に起源をなし、同23年 6 月21日の建箱挂の発足をもって組辕としての成立をなす、 としている。また同文献によると、明治16年〜大正 7 年の文 部省営結組䄉の技師17名のうち、10名が建築高等教育歴をも つ者であった、とされている。

6) 明治期の学校建築における文部省の規定のなかて、洋小屋使 用に関するものは、標準設計例としての小屋組が示されてい

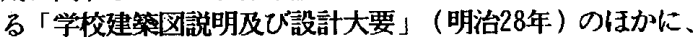
「学校建築設計要項」(明治37年) 等がある。

7 ) 日本建学会: 近代日本建筑学発達史, 昭和47年によれば、 トラス構造の学術的研究が始まるのは明治20年前後である、 とされている。

（1995年11月 9 日原稿受理，1996年 4 月22日採用決定） 